\title{
The Relationship of Organizational Culture, Transformational Leadership, and Personality to Organizational Citizenship Behaviour (OCB)
}

\author{
${ }^{1}$ Ai Rukmini, ${ }^{2}$ Soewarto Hadhienata, ${ }^{3}$ Rita Retnowati \\ ${ }^{1}$ Post Graduate Program, Universitas Pakuan Bogor, Indonesia
}

\begin{abstract}
The purpose of this study is to examine the relationship of organizational culture, transformational leadership, and personality with Organizational Citizenship Behaviour (OCB) teachers, either individually in group. This study was conducted on 202 teachers of civil servants selected by multistage Proportional Sampling of 11 junior high school in Bogor City. This study used a type of combination methods that is sequential explanatory design that begins with a quantitative study then deepened with qualitative research. The purpose qualitative research after the implementation of quantitative research is to obtain a clarification of the results of quantitative research, wether qualitative research deepens, proves and gives meaning to quantitative data or otherwise aborts the results of quantitative research. The research concludes there is positive and significant relationship and it is strengthened by the results of qualitative research that: 1) There is positive significant correlation between organizational culture with $O C B$ ry $1=0.234\left(R^{2} y_{1}=11.2 \%\right)$ with the regression equation $\hat{\mathrm{Y}}=84,66+0,33 \mathrm{X}_{1} .2$ ). There is positive significant correlation between transformational leadership with OCB ry2 $=0.446\left(R^{2}=19.8 \%\right)$ with the regression equation $\left.\hat{\mathrm{Y}}=72,77+0,44 \mathrm{X}_{2} .3\right)$ There is positive significant correlation between personality with $O C B$ ry3 $=0.659\left(R^{2}=43.5 \%\right)$ with the regression equation $\hat{\mathrm{Y}}$ $\left.=46,36+0,70 \mathrm{X}_{3} .4\right)$ There is positive significant correlation between organizational culture, transformational leadership, and personality together with $O C B$ ry $123=0,700\left(R^{2} y_{123}=48.9 \%\right)$ with regression equation $\hat{\mathrm{Y}}=$ $19,44+0,08 \mathrm{X}_{1}+0,22 \mathrm{X}_{2}+0,58 \mathrm{X}_{3}$. The quantitative research results are reinforced by the qualitative research.
\end{abstract}

Keywords: Organizational Culture, Transformational Leadership, Personality Organizational Citizenship Behaviour (OCB)

\section{INTRODUCTION}

The school as an organization should be managed in such a way that the activity of educational program implementation can be run effectively, efficiently and productively to achieve educational goals. The success of the goals of education in schools depends on the human resources available in the schools, the principals, teachers, students, staff administration and other personnel education.

In the context of organizational behavior where teachers are facing a number of demands of the role of the profession and their limitations to meet what is expected from the profession, the teachers are required to perform an extra role of the profession known as Organizational Citizenship Behaviour (OCB). Organizational Citizenship Behaviour is the contribution of individuals exceeding a role in the job .OCB involves multiple behaviors including helping others, volunteering for extra duties, adherence to the rules and procedures in the workplace and people featuring extra role behavior is referred to as a good employee (good citizen).

The government had rewarded teachers in the form of allowance as an effort to enhance the dignity and welfare but it is still encountered teachers who do not perform as expected. Most teachers do not have awareness, concern and responsibility in maintaining and caring school environment respectively. Sometimes teachers respond and perform tasks with less responsibility, just come to school when teaching only, often escape with no apparent reason, arrive late, do not understand teaching methods, less devoted to the students, do not use the time effectively, and did not prepare a lesson plan well besides less enthusiasm in promoting and developing competence. Furthermore, efforts to establish a cooperative relationship with co-teachers inside and outside of working hours has not been well established and effective. 
The results of preliminary research conducted on 30 teachers Junior High School in the city of Bogor, Indonesia obtained $43.84 \%$ of respondents have not shown good OCB. Overall there is a gap between OCB of teachers and preliminary research results (score 56.16\%) with OCB of teachers expected (a score of $100 \%$ ) in order to function in the organization well.

Based on this background, studies relating to the factors that allow for increased OCB of teachers are necessary together with Organizational Culture, Transformational Leadership, and Personality as these are interesting factors to note non how to improve their relations and influence in Junior High School teachers in the city of Bogor, Indonesia.

The problem studied in this research is then formulated in the form of following questions:

1. Is there a relationship between Organizational Culture to the teachers' OCB?

2. Is there a relationship between transformational leadership to teachers' OCB?

3. Are there any ties between personality to teachers' OCB?

4. Is there any relationship between Organizational Culture, Transformational Leadership and Personality to teachers' OCB simultaneously?

\section{LiteratURE REVIEW}

According to Spector (2009) OCB is a behavior that goes beyond the requirements of the core tasks of the work (tasks listed in the job description) and beneficial for the organization. Podsakoff et.al (2000) define OCB as individual behavior that is discretionary, which does not directly and explicitly receive an award from the formal reward system, and the overall effectiveness encourage organizational functions, free and voluntary, behavior is not required by the terms of role or position description that clearly required under a contract with the organization; but as a personal choice.

In line with previous theories, Gibson, et.al (2006) stated that OCB is the behavior of an individual to perform work outside the assignment with an effective and efficient manner without regard to reward or bonus, but supports the value of the organization, with the indicator as follows: a) doing a good job for the organization and its customers, asking nothing in return b) motivation to constantly improve skills, c) building a climate of high quality performance, trying to increase productivity, and quality of production.

Luthans (2011) defined OCB as a free individual behavior, not directly or explicitly recognized by the formal reward system, and overall improve the effective functioning of the organization. The cornerstone of OCB personality reflects the nature of employees to be cooperative, helpful, caring and careful attention to words. OCB can take many forms, but the main ones can be summarized as follows:

a) Altruism (e.g helping a co-worker who was absent)

b) Conscientiousness (e.g working through time to complete the project),

c) Civic virtue (e.g voluntarily representing companies / organizations on programs / community activities)

d) Sportsmanship (e.g sharing the experience of handling the failure of a project team by following the advice of the team towards the success of the project), and

e) Courtesy (e.g, mutual understanding and empathy among employees).

From the definition above theory, it can be synthesized that Organizational Citizenship Behavior (OCB) is the behavior of the extra roles of individuals in an organization that is voluntary, free and work exceeded the core task and explicitly not awarded formally so overall can improve the effectiveness of the organization, Indicators OCB are: 1) the behavior of helping others (altruism), 2) awareness and caution in his involvement in the activities of the organization (conscientiousness), 3 ) tolerance of the situation is not ideal in the workplace (sportsmanship), 4) respect and mutual help inform (courtesy), 5) responsible and caring citizens to abide by the rules (civic virtue).

According to Jennifer and Gareth R. Jones (2008) organizational culture is a form of role of values, beliefs and norms that affect the way employees to think, feel and behave towards each other and towards those outside the organization. 
According to Ivancevich et.al ( 2008) Organizational culture is a system of collective thinking that became a handbook for members of an organization that can differentiate their organizations and other organizations, with factors, that organization is the brainchild and consensus in determining the direction of policy, what products will be produced, who have identity cards, to make it different from other organizations.

Meanwhile,Luthan (2011) explores six crucial characteristic of the culture of the organization, namely: (1) observed behavioral regularities that manage way of observable acting of the members when members of the organization interact with other members, they may use a common language, terms, or certain rituals; (2) norms; the various existing standards of conduct, including guidelines on the extent to which a job to be done; (3) the dominant values; that is the core values that are shared by all members of the organization, for example on high product quality, low attendance or high efficiency; (4) philosophy; namely the existence of policies with regard to confidence in the organization treats its customers and employees (5) rules; namely the existence of strict guidelines, associated with the advancement of the organization (6) organization climate; an overall feeling portrayed and conveyed through the spatial conditions, how to interact with the members of the organization, and how the organization's members and customers treat themselves or others. Cultural organizations are all traits that indicate the habit of an organization, a shared belief, values and behaviors shared by all members of the organization. An organizational culture is a tradition that is very difficult to change.

James L. Gibson, John M. Ivancevich, James H. Donnelly, and Robert Konopaske (2008) define organizational culture is a perspective to understand each other's behavior of individuals and groups within the organization that each has limitations. Organizational culture can be symbols, language, ideology, rituals and myths that are a product of the behavior. School is an organization, and culture in the school level is the organization's culture. The main recipe of organizational culture is a collective interpretation carried out by members of the organization and the results of its activities.

Based on some of the above theory, it can be synthesized that organizational culture is the values, rules and beliefs policies that determine how perceptions of ways of thinking, and the reaction member to the environment as well as being a guide in organizational attitude. The indicators in the organization's culture is the norm, values, attitudes, beliefs and adaption to the environment in order achieving organizational goals.

Yukl (2006) defines Transformational leadership as the leadership that affects followers to feel trusted, admired, loyal and respected for leaders and motivate them to do more than is expected.

Theory formulation of transformational leadership behaviors consists of four components:

1. Idealized influence emphasizes the type of leader that shows trust, confidence, and admired praised by followers.

2. Inspirational motivation emphasizes on how to motivate and inspire subordinates to the challenging task. Its influence is expected to boost the spirit of the group.

3. Intellectual stimulation emphasizes the type of leader who is trying to encourage subordinates to think of innovation, creativity, methods or new ways.

4. Individualized consideration emphasizes the type of leader who gives attention to the development and achievement needs of subordinates.

Colqiutt et.al (2009) explains that transformational leadership is leadership that involves inspiring all members to commit in order towards a common vision that gives meaning to their own development potential and some of the problems from a new perspective. Transformational leadership is seen from the above definition of an approach to a high motivation to lead than other managerial approach.

Angelo Kinicki and Brian K. Williams (2008) explained that transformational leadership is the leadership that transforms employees to pursue personal interests exceed organizational goals. A transformational leader will seek to influence, move and develop leadership to others. A transformational leader is influenced by two factors; namely: 1) the individual characteristics; includes personalities leaders tend to be more extroverted, fun, and proactive. 2) Cultural organizations; cover adaptive, flexible organizational culture are more likely than the rigid and 
bureaucratic culture to encourage transformational leadership. The transformational leader has four main types of behavior to influence his followers; namely: 1) Inspiration motivation, leaders always give freedom to its members to develop a vision, mission, and goals of the organization, charismatic, realistic, credible and attractive future of the organization. 2). Ideal influence; able to inspire the confidence of followers, because it is consistent, sincere and persistent in the pursuit of organizational goals. 3). Individuals who are thoughtful; actively encourages followers to grow and excel by giving them challenging work, more responsibility, empowerment, and one-on-one mentoring and 4). Intellectual stimulation; leaders who are gifted in communicating the strengths, weaknesses, opportunities, and threats so that subordinates develop a new sense of purpose of the organization.

Robbins (2013) said that the characteristics of transformational leaders, namely: (a) has charisma, which provide a vision and a sense of the mission, instilling pride, won the respect and trust, (b) Inspiration, which communicates high expectations, uses symbols to focus on the business, and describes the intent important in a simple, (c) intellectual stimulation, which is to encourage intelligence, rationality, and solve problems carefully, (d) consideration of the individual, namely providing personal attention, airport personally, coaching and mentoring.

Based on a number of the above theory, it can be synthesized that, transformational leadership is the behavior of a leader who is able to influence his followers to achieve the vision and a common goal, which is the alignment of leaders, followers of the organization through the influence of the idealism of followers who bring a sense of pride and trust, inspire and motivate, foster creativity and innovation, treated individually always guide and give direction to his followers. The indicators that show transformational leadership are: 1) charisma, 2) individual consideration, 3) influence on thought of ideal citizens, 4) the inspiration that motivated, 5) intellectual stimulus, and 6) innovation.

Personality is the dynamic organization of the psychophysical system in man who helped establish a pattern of behavior, thoughts and feelings, unique or distinctive in adapting to the environment.

Robbins (2013) observed the human personality through traits of personality, namely: openness to experience, conscientiousness, extraversion, agreeableness, and emotional stability as the opposite of neuroticism. This approach is known as the big five model of personality.

According Ivancevich, Konopaske, and Matteson (2008) personality refers to a set of stable feelings and behaviors that significantly shaped by genetic factors and the environment.

James Gibson et. al (2012) provides limits of personality as a set of stable characteristics and trends that determine similarities and differences in people's behavior. Five dimensions or factors can be used to describe a large number of human personality. These factors are as follows:

1. Conscientiousness (conscientiousness). The behavior is described as hard working, diligent, organized, reliable, and persistent. Individuals who scored high on conscientiousness tend to have high levels of motivation and perform well in various types of work.

2. Extraversion-introversion indicates the degree of sociable person. A gregarious and assertive personality trait indicate extraversion that usually show good performance and a high level of job satisfaction.

3. Agreeableness is the level of good cooperation with the shared trust, warmth, and mutual cooperation. Someone with high hospitality tends to be a better team player and get along well with colleagues, customers and other stakeholders.

4. Emotional Stability refers to person's ability to control stress by staying calm, focused, and confident. Individuals who have a good level of emotional stability or higher tend to have high levels of performance and stay longer with the organization.

5. Openness to experience is the level of interest in someone or new things. Open individuals are creative, full of curiosity, and sensitive to artistic things and tend to develop higher level of openness in the work field.

Based on the description above, it can be synthesized that personality is the overall properties of an individual that is likely to be stable to react and interact with other individuals and the environment that could explain the characteristic patterns of thought, emotion, and behavior with the indicators: 1) Openness to experience which reflects the nature of having extensive knowledge, thinking and acting creatively, full of curiosity to the problem, knowledge and evolving technologies 2). Be careful 
(conscientiousness), the nature of full of responsibility, persistent work with organized and planned, trustworthy and reliable, 3). Extraversion , the nature of teachers whose high morale in work, happy and sociable, and easily motivated by change, 4). Agreeableness, the nature of teachers whose high empathy so always avoid conflict, tend to be cooperative because having a high level of trust to colleagues, and 5). Emotional Stability, the nature of teachers who are not prone to stress and feel comfortable in working tough with excessive workload.

Based on the literature review the following hypothesis is formulated:

1. Organizational culture positively affects teachers' organizational citizenship behavior.

2. Transformational leadership positively affects teachers' organizational citizenship behavior.

3. Personality positively affects teachers' organizational citizenship behavior.

4. Organizational culture, transformational leadership and personality simultaneously affect teachers' organizational citizenship behavior.

\section{Data Collection}

This study applies mix method with direct observation to the field aimed at analyzing the phenomenon occur when the research took place then confirm the finding by using direct depth interview. This way, writers apply Sequential Explanatory Mixed Methods. Descriptive statistics and quantitative analysis are used for finding initial solution to the problem encountered. The sampling technique is to count the number of samples by using the Slovin's formula generating samples obtained as many as 202 out of 408 teachers.

Techniques of data collection in this study is in the form of questionnaire.. Analysis is conducted with multiple linear regression and hypothesis testing is performed at a significance level of 0.05 .

\section{RESUlt AND DisCuSSION}

The teachers of listed organizations were asked to participate in the survey by responding their opinions for four different measures in Organizational Culture, Transformational Leadership, and Personality to Organizational Citizenship Behavior.

\subsection{The Effect of Organizational Culture to Organizational Citizenship Behavior}

Hypothesis testing confirms that Organizational Culture positively affects Organizational Citizenship Behavior with correlation coefficient value of 0.234 and the coefficient of determination $=0.112$ with the regression equation $\hat{\mathrm{Y}}=84.66+0.33 \mathrm{X} 1$. This means that only $11.2 \%$ of Organizational Citizenship Behavior is determined by Organizational Culture, while the other $88.8 \%$ is contributed by other variables. Similarly, result of qualitative research interviews, observation and documentation confirms the tendency of the relationship between Organizational Culture to Organizational Citizenship Behavior. This finding strengthens the quantitative research hypothesis results testing that there is a positive significant relationship between Organizational Culture to Organizational Citizenship Behavior.

This finding is in line with Omar (2013) that organizational culture which form the role of values, beliefs and norms that affect the way employees to think, feel and behave towards each other and towards those outside the organization will positively affect the OCB of employees.

\subsection{The Effect of Transformational Leadership to Organizational Citizenship Behavior}

Hypothesis testing confirms that Transformational Leadership positively affects Organizational Citizenship Behavior with correlation coefficient value of 0.446 and the coefficient of determination = 0.198 with the regression equation $\hat{Y}=72.77+0.44 \mathrm{X}_{2}$. This means that only $19.8 \%$ of Organizational Citizenship Behavior is determined by Transformational Leadership, while the other $80.2 \%$ is contributed by other variables. Similarly, result of qualitative research interviews, observation and documentation confirms the tendency of the relationship between Transformational Leadership to Organizational Citizenship Behavior. This finding strengthens the quantitative research hypothesis results testing that there is a positive significant relationship between Transformational Leadership to Organizational Citizenship Behavior. 
This finding is in line with Rahmi (2014) that transformational leadership reflecting the behavior of a leader who is able to influence his followers to achieve the vision and a common goal, which is the alignment of leaders, followers of the organization through the influence of the idealism of followers who bring a sense of pride and trust, inspire and motivate, foster creativity and innovation, treated individually always guide and give direction to his followers will positively affect the OCB of employees.

\subsection{The Effect of Personality to Organizational Citizenship Behavior}

Hypothesis testing confirms that Personality positively affects Organizational Citizenship Behavior with correlation coefficient value of 0.659 and the coefficient of determination $=0.435$ with the regression equation $\hat{Y}=46.36+0.70 X_{3}$. This means that only $43.5 \%$ of Organizational Citizenship Behavior is determined by personality while the other $57.5 \%$ is contributed by other variables. Similarly, result of qualitative research interviews, observation and documentation confirms the tendency of the relationship between Personality to Organizational Citizenship Behavior. This finding strengthens the quantitative research hypothesis results testing that there is a positive significant relationship between Personality to Organizational Citizenship Behavior.

This finding is in line with Purba \& Seniati (2010) that personality which is is the overall properties of an individual that is likely to be stable to react and interact with other individuals and the environment that could explain the characteristic patterns of thought, emotion, and behavior positively affects Organizational Citizenship Behavior.

\subsection{Interaction of Organizational Culture, Transformational Leadership, and Personality to Organizational Citizenship Behavior}

When tested together, hypothesis testing results show that there is a significant relationship between Organizational Culture, Transformational Leadership, Personality to Organizational Citizenship Behavior. The regression equation generated is $\hat{\mathrm{Y}}=19.44+0.08 \mathrm{X}_{1}+0.22 \mathrm{X}_{2}+0.58 \mathrm{X}_{3}$ with correlation of coefficient values $=0.7000$ and the coefficient of determination $=0.490$. This means that $49 \%$ of Organizational Citizenship Behavior is caused by variables of Organizational Culture, Transformational Leadership, Personality while $51 \%$ is contributed by other variables not included in the model. Result of qualitative research interviews, observation and documentation in the respective schools also confirms the relationship among Organizational Culture, Transformational Leadership, Personality to Organizational Citizenship Behavior. This finding strengthens the quantitative research hypothesis results testing that there is a positive significant relationship among those mentioned variables. Qualitative research also reveals that other factors affecting Organizational Citizenship Behavior in the respective school are school's facility and teachers' welfare which is viewed as less optimal.

\section{Conclusion}

The findings reveal that there is a positive and significant direct effect between the transformational leadership, personality and job satisfaction to organizational commitment.

Based on the initial design of the constellation between variables, the results showed that the contribution of transformational leadership to organizational commitment is $33.9 \%$, personality is $2.8 \%$, and job satisfaction is $7.1 \%$ indicating the highest individual contribution to the lecturers' organizational commitment is transformational leadership. When combined together, contribution of the three variables reaches $44 \%$ indicating the contribution of other variables not included in the model to predict organizational commitment are $56 \%$ confirming this model is of marginal-fit. Other researchers wishing to conduct similar studies may include other variables such as; teachers' professionalism, achievement motivation, work culture of teachers, teachers' resilience, creativity, work experience, training, management, decision-making techniques and so forth. This confirms Syahril \& Widyarini 's (2011) discernment that it is required to conduct an inclusive and critical investigation to identify the factors that heighten and boost organizational citizenship behavior. Factors related to personal characteristics, organizational environment, and leadership behaviors recovered to foretell various types of organizational citizenship behavior mainly within junior high school teachers' context which are hardly investigated. 
The Relationship of Organizational Culture, Transformational Leadership, and Personality to Organizational Citizenship Behaviour (OCB)

\section{REFERENCES}

Angelo Kinicki and Brian K. Wiliams. Management A practical Introduction, New York:Mc Grow Hill,2008.

Colquitt, J.A, LePine, and Wesson. Organization Behaviour; Improving Performance, Comitment in the Workplace, Second Edition. New York: Mc Grow Hill.2009.

Gibson James M. Organizations: Behavior, Structur, Processes, International Edition, New York: Mc Graw-Hill Companies, 2006.

Ivancevich, Konopaske and Matteson, Organizational Bahavior and Management, $8^{\text {th }}$ Edition, McGraw Hill, 2008.

James L. Gibson John M. Ivancevich, James H. Donelly, Jr. Robert Konopaske. Organizations Behavior, Structure, Processes, New York: McGraw-Hill Irwin, 2012.

Jennifer M. Georde and Gareth R .Jones, Understanding and Management: Behaviour. New Jersey .Person Education, Inc Upper Saddle River. 2008.

Luthans, Fred. 2011. Organizational behaviour: An Evidence-Based Approach, Mc Graw-Hill Irwin Companies, 2011.

Oemar, Y. (2013). Pengaruh Budaya Organisasi, Kemampuan Kerja dan Komitmen Organisasi terhadap Organizational Citizenhsip Behavior (OCB) Pegawai pada BAPPEDA Kota Pekanbaru. Jurnal Aplikasi Manajemen, 11(1), 65-76.

Podaskoff, P.M., MacKenzie, S.B., Paine, J.B, and Bachrach, D.G. Organizational Citizenship Behaviors: a critical review of the theoretical and empirical literature and suggestion for future research. Journal Management Vol.26. No. 3. 2000.

Purba, D. E., \& Seniati, A. N. L. (2010). Pengaruh Kepribadian dan komitmen organisasi terhadap Organizational Citizenzhip Behavior. Makara Hubs-Asia, 8(3).

Rahmi, B. M. (2014). Pengaruh Kepemimpinan Transformasional Terhadap Organizational Citizenship Behavior dan Komitmen Organisasional dengan Mediasi Kepuasan Kerja (Studi pada Guru Tetap SMA Negeri di Kabupaten Lombok Timur). E-Jurnal Manajemen Univers- itas Udayana, 3(2).

Robbins, Stephen P. Organizational Behavior, Upper Saddle River, New Jersey Prentice-Hall Inc.2013.

Syahril, N., \& Widyarini, M. N. (2011). Kepribadian, kepemimpinan transformasional, dan perilaku kewargaorganisasian. Jurnal Ilmiah Psikologi, 1(1).

Spector, Paul E. Industrial and Organizational Psychology Reseach and Practice.5 th Edition. USA.Jhon Willey \& Sons, Inc. 2008.

Yukl, Gary. Leadership in Organizations. New Jersey: 2006. 